\title{
Experimental Studies of a Coronavirus and Coronavirus-Like Agent in a Barrier-Maintained Feline Breeding Colony
}

\author{
By \\ C. A. Stoddart, J. E. Bartodgh, and F. W. Scott \\ Cornell Feline Health Center and Department of Microbiology, \\ New York State College of Veterinary Medicine, Cornell University, \\ Ithaca, New York, U.S.A. \\ With 1 Figure \\ Accepted August 15, 1983
}

\begin{abstract}
Summary
Ninimal-disease (MD) cats raised in a barrier-maintained feline breeding colony routinely become coronavirus (CV) antibody-positive at 5-8 weeks of age and remain seropositive indefinitely. In addition, they shed coronavirus-like particles (CVLPs) in their feces which are morphologically distinct from "typical" coronaviruses. Oronasal, intraperitoneal, intraduodenal, and intravenous inoculations of CVLPs were uniformly unsuccessful in the seroconversion of cats to $\mathrm{CV}$, whereas subsequent prolonged close contact with colony cats did result in seroconversion. Such evidence indicates that MD cats in this barrier colony are infected with at least two non-crossreactive agents: (1) feline enteric CVLPs, which are shed in feces and are morphologically and antigenically distinct from established coronaviruses $(\mathrm{CVs})$, and (2) a virus which is antigenically cross-reactive with $\mathrm{CVs}$, but which is apparently shed by some route other than the lower gastrointestinal tract.
\end{abstract}

\section{Introduction}

Feline infectious peritonitis virus (FIPV) is a recognized member of the family Coronaviridae $(2,18)$ and is antigenically related to transmissible gastroenteritis virus (TGEV) of swine, canine coronavirus (CCV), and human respiratory coronavirus $229 \mathrm{E}$ (HCV 229E) (8, 15, 17, 20). FIPV-like particles have been identified in the gastrointestinal tracts of some cats with feline infectious peritonitis (FTP) $(6,7)$ and enteritis $(5,14)$, and in feces of apparently healthy cats (N. C. PEDERSEN, personal communication). An enteric virus morphologically and antigenically similar to FIPV has been reported from cats reared in a conventional feline breeding colony maintained 
by Animal Resources Services, University of California, Davis (14), and is referred to here as FECV (UCD). This virus was initially detected in feces of healthy cats but was shown to be capable of producing mild pyrexia, leukopenia, and enteritis when fed experimentally to young kittens (14). Coronavirus-like particles morphologically distinct from EIPV have been detected in feces of clinically normal cats $(10,11)$ and in feces of some cats with enteric disease (10). These latter particles were first visualized by electron microscopy (EM) in feces of MD cats raised in a barrier feline breeding colony maintained by the Division of Laboratory Animals Services, New York State College of Veterinary Medicine, Cornell University (11). Feline enteric CVLPs have since been detected by EM in 20 of 185 (10.8 percent) fecal samples from privately-owned cats hospitalized at the small animal clinic of the Veterinary Medical Teaching Hospital at Cornell (10). While morphologic and antigenic similarities exist between FIPV and FECV (UCD), the morphologically dissimilar CVLPs appear to be antigenically dissimilar as well (11).

In this paper we describe transmission experiments involving feline enteric CVLPs and present evidence that MD eats in the Cornell University feline breeding colony are infected with at least two non-cross-reactive agents: (1) feline enteric CVLPs, which are shed in feces and are morphologically and antigenically distinct from the FIPV/TGEV group, and (2) a CV which is antigenically cross-reactive with the FIPV/TGEV group, and which is apparently shed by some route other than the lower gastrointestinal tract.

\section{Materials and Methods}

\section{Viruses}

Feline enteric CVLPs were initially obtained from fresh fecal material collected from the MD feline breeding colony maintained by the Division of Laboratory Animal Services, Cornell University. An additional source was an experimental cat inoculated with CVLPs and which subsequently shed particles during the course of this study. Fecal material was diluted $1: 2$ in 0.1 ur phosphate buffered saline (PBS), pH 7.4, and clarified by centrifugation at $2000 \times g$ for 10 minutes at $4^{\circ} \mathrm{C}$. Supernatants were further elarified by ultracentrifugation at $10,000 \times g$ for 10 minutes at $4^{\circ} \mathrm{C}$ and then pelleted at $110,000 \times g$ for 1 hour at $4^{\circ} \mathrm{C}$. Pellets were resuspended in $5-10 \mathrm{ml}$ of either doubledistilled water (DDW), pH 7.0 (for oronasal [o.n.] and intraduodenal [i.d.] inoculations) or PBS (for intraperitoneal [i.p.] and intravenous [i.v.] inoculations). This procedure produced highly-concentrated CVLP suspensions. To sterilize the i.p. and i.v. inocula, the PBS resuspensions were filtered successively through 800 - and $450-\mathrm{nm}$ filter units (Sybron/Nalge, Rochester, New York), pelleted, and suspended again as described above. They were then filtered through 450-nm Acrodise filters (Gelman Sciences, Ine., Ann Arbor Michigan,). Crude estimates of the number of particles $/ \mathrm{ml}$ of each inoculum were made by EM (12). Inocula were stored at $4^{\circ} \mathrm{C}$ for no longer than 24 hours prior to inoculation into experimental animals.

MD kittens from the Cornell feline breeding colony were ased as a source of TGEV. cross-reactive CV for direct cat-to-eat transmission. 
For morphologic comparison of CVs by EM, the following additional viruses were used: FECV (UCD) and FIPV (WSU 79-1146) (both kindly provided by N.C. Pedersen, University of California, Davis) and TGEV, Miller strain (obtained from the New York State Diagnostic Laboratory, Comell University). FECV (UCD) was supplied as a crude fecal suspension from infected cats, while both FIPV and TGEV were supplied as clarified cell culture preparations.

\section{Experimental Animals}

Nine 12-week-old CV antibody-negative and enteric CVLP-negative MD kittens were purchased from a commercial breeding colony (Liberty Laboratories, Liberty Corner, New Jersey) (Liberty cats). Four 6-week-old CV antibody-negative MD kittens were obtained from the barrier-maintained Comell feline breeding colony (Cornell cats). Cats from the Cornell colony routinely become CV antibody-positive at 58 weeks of age (C. A. STODDART, unpublished data) and remain seropositive indefinitely. All animals were housed singly in negative-pressure fiberglass isolation cages (Germfree Laboratories, Inc., Miami, Florida) which were specially equipped for maximal air exchange. Strict isolation procedures were followed in the care of cats throughout these experiments. To further minimize cross-contamination between groups, experimental and control cats were cared for on altemate days.

\section{Electron Microscopy}

Fecal samples for electron microscopy were collected from litter pans and stored at either $4^{\circ}$ or $-80^{\circ} \mathrm{C}$ until preparation, at which time a $30-50$ percent suspension was made of each sample in DDW. Samples were clarified by centrifugation at $2000 \times g$ for 10 minutes at $4^{\circ} \mathrm{C}$, further clarified by ultracentrifugation at 10,000 for 10 minutes, at $4^{\circ} \mathrm{C}$, and then pelleted at $110,000 \times g$ for 1 hour at $4^{\circ} \mathrm{C}$. Pellets were resuspended in $5-10$ drops of DDW and stored at either $4^{\circ}$ or $-80^{\circ} \mathrm{C}$. For EM examination samples were negatively stained by mixing 1 drop of fecal suspension with $7-10$ drops of 0.01 percent bacitracin and 2-4 drops of 3.5 percent phosphotungstic acid (PTA), $\mathrm{pH}$ 7.0. Each mixture was then sprayed onto a carbon- and parlodion-coated 200 mesh copper grid with a glass nebulizer and examined in a Philips 201 electron microscope. Individual samples were examined for an average of 12 minutes and no less than 6 minutes, unless CVLPs were visualized sooner. Samples were not scored positive unless $\geq 2$ particles were found.

\section{Serology}

Serum coronaviral antibody titers were determined using the Miller strain of TGEV in a kinetics-based ELISA (KELA), as previously described (1). This assay has been shown to produce results which are comparable to the conventional heterologous immunofluorescence assay (IFA) (1). KELA titers $\leq 1: 8$ were considered negative.

\section{Inoculation of Liberty Cats with Feline Enteric CVLPs}

Seven Liberty cats $(A-G)$ were inoculated with feline enteric CVLP suspensions by various routes. Control cats ( $H$ and $I$ ) were given an equal volume of sterile diluent used to resuspend pellets. Chronology of inoculations is shown in Table 1. Inoculation 6 was actually performed by natural exposure to an infected carrier cat for 72 days. For i.d. inoculation, cats were anesthetized and abdominal incisions made in order to inject inoculum directly into the duodenum, $4 \mathrm{~cm}$ posterior to the pyloric sphincter (control inoculations were not performed for this experiment). In inoculation 8, two concurrent doses were given, one i.v, and one o.n. For i.v. inoculation, CVLP suspensions were injected into either the jugular or cephalic vein. Fecal and serum samples were obtained from all cats before and after each inoculation. Fecal samples were 
Table 1. Chronology of experimental inoculations of Liberty cats with feline enteric coronavirus like particles (CVLPs)

\begin{tabular}{|c|c|c|c|c|c|c|c|}
\hline $\begin{array}{l}\text { Inocu- } \\
\text { lation } \\
\text { no. }\end{array}$ & $\begin{array}{l}\text { Experi- } \\
\text { mental } \\
\text { cats } \\
\text { used }\end{array}$ & $\begin{array}{l}\text { Control } \\
\text { cats } \\
\text { used }\end{array}$ & $\begin{array}{l}\text { No. of } \\
\text { particles } \\
\text { administered }\end{array}$ & $\begin{array}{l}\text { Source } \\
\text { of } \\
\text { CVLPs }\end{array}$ & $\begin{array}{l}\text { No. of } \\
\text { doses } \\
\text { interval } \\
\text { between } \\
\text { doses) }\end{array}$ & $\begin{array}{l}\text { Route } \\
\text { of } \\
\text { inocu- } \\
\text { lation }\end{array}$ & $\begin{array}{l}\text { No. of } \\
\text { days } \\
\text { observed } \\
\text { after } \\
\text { inocu- } \\
\text { lation }\end{array}$ \\
\hline 1 & $\mathrm{~A}, \mathrm{~B}, \mathrm{C}$, & $\mathrm{H}, \mathrm{I}$ & $10^{7}$ & Colony & 1 & $o . n$. & 50 \\
\hline 2 & $A, C$ & $\mathrm{H}, \mathrm{I}$ & $10^{6}$ & Cat B & $\begin{array}{l}4 \\
(12 \\
\text { hours })\end{array}$ & $o . n$. & 33 \\
\hline 3 & $A$ & I & $10^{7}$ & Cat B & $\begin{array}{l}5 \\
(12 \\
\text { hours })\end{array}$ & $o . n$. & 35 \\
\hline 4 & $\mathrm{C}$ & $\mathrm{H}$ & $10^{6}$ & Cat B & 1 & i.p. & 35 \\
\hline 5 & $\mathrm{D}, \mathrm{E}, \mathrm{G}$ & $\mathrm{H}, \mathrm{I}$ & $10^{6}$ & Cat B & $\begin{array}{l}2 \\
(24 \\
\text { hours })\end{array}$ & $o . n$. & 35 \\
\hline $6^{b}$ & $\mathrm{~F}$ & $\mathrm{ND}^{\mathrm{c}}$ & Undetermined & Cat B & - & $\begin{array}{l}\text { Natural } \\
\text { exposure }\end{array}$ & 60 \\
\hline 7 & $\mathrm{D}, \mathrm{E}$ & ND & $10^{6}$ & Cat B & 1 & i.d. & 48 \\
\hline 8 & $F, G$ & $\mathrm{H}, \mathrm{I}$ & $\begin{array}{l}10^{7} \\
10^{6}\end{array}$ & Colony & $\begin{array}{l}1 \\
1\end{array}$ & $\begin{array}{l}\text { i.v. } \\
\text { o.n. }\end{array}$ & 45 \\
\hline 9 & $\begin{array}{l}\mathrm{A}, \mathrm{B}, \mathrm{C}, \\
\mathrm{D}, \mathrm{E}\end{array}$ & $\mathrm{H}, \mathrm{I}$ & $10^{7}$ & Colony & 1 & i. v. & 21 \\
\hline
\end{tabular}

a o.n.=oronasal; i.p. =intraperitoneal; i. d. =intraduodenal; i.v. =intravenous

b Natural exposure to an infected carrier cat (cat B) for 27 days

c $\mathrm{ND}=$ not done

collected and examined for CVLPs by EM 3 times weekly for the experimental cats and once weekly for control cats. Serum samples were collected from each cat at approximate 2 -week intervals.

\section{Transmission of Cornell Colony $\mathrm{CV}$ to Liberty Cats}

Each of 4 Cornell MD kittens (1-4) was placed in the same cage with Liberty cats $B, D, E$, and $G$, respectively. Two cats ( $H$ and $I$ ) were used as room controls. Serum samples were collected from all cats near or at the time of introduction and at 2-4 week intervals thereafter. Kittens were separated from the Liberty cats after 55 days at which time individual fecal samples from all cats were collected and examined by EM.

\section{Results}

Inoculation of Liberty Cats with Feline Enteric CVLPs

Prior to inoculation, all Liberty cat serum and fecal samples were CV antibody-negative and CVLP-negative respectively, After inoculation 1 (Table 1), cat B began shedding CVLPs in feces 14 days after inoculation. 
This cat continued to shed particles intermittently throughout the course of this experiment and until the time of manuscript preparation (a total period of 12 months). Many CVLPs $(50-100)$ were observed within the first 1-2 minutes of EM seareh in most fecal samples which were CVLPpositive. CVLPs were visualized in only 2 fecal samples collected 47 and 49 days after inoculation from cat $\mathrm{F}$ after natural exposure to infected carrier cat $B$. All fecal samples from control cats $H$ and I were CVLP-negative. Throughout the inoculations all experimental and control cats remained $\mathrm{CV}$ antibody-negative and no clinical signs of disease were seen.

\section{Transmission of Cornell Colony CV to Liberty Cats}

Results from this experiment are shown in Table 2. Serum samples from all cats were $\mathrm{CV}$ antibody-negative prior to introduction. By 15 days after introduction, 3 out of 4 (75 percent) of the Cornell colony cats had sero-

Table 2. Seroconversion of $C V$ antibody-negative Liberty cats by natural exposure to Cornell colony cats

\begin{tabular}{|c|c|c|c|c|c|c|c|c|c|c|c|c|}
\hline \multirow[b]{2}{*}{$\mathrm{Cat}^{\mathrm{a}}$} & \multicolumn{7}{|c|}{$\begin{array}{l}\text { Reciprocal CV antibody titer (KELA) } \\
\text { (days after introduction) }\end{array}$} & \multicolumn{5}{|c|}{$\begin{array}{c}\text { CVLPs (EM) }{ }^{\circ} \\
\text { (days after introduction) }\end{array}$} \\
\hline & -11 & 0 & 15 & 45 & 71 & 100 & 122 & -4 & 56 & 66 & 72 & 122 \\
\hline \multicolumn{13}{|c|}{$\begin{array}{l}\text { Cornell } \\
\text { cats }^{d}\end{array}$} \\
\hline 1 & $\mathrm{ND}^{\mathrm{e}}$ & neg. & neg. & 21 & 16 & ND & $\mathrm{ND}$ & $\mathrm{ND}$ & + & + & ND & $\mathrm{ND}$ \\
\hline 2 & $\mathrm{ND}$ & neg. & 40 & 80 & 213 & ND & $\mathrm{ND}$ & $\mathrm{ND}$ & - & - & - & $\mathrm{ND}$ \\
\hline 3 & ND & neg. & 12 & 52 & 164 & ND & $\mathrm{ND}$ & $\mathrm{ND}$ & + & + & ND & ND \\
\hline 4 & $\mathrm{ND}$ & neg. & 15 & 98 & 141 & ND & $\mathrm{ND}$ & ND & + & + & $\mathrm{ND}$ & $\mathrm{ND}$ \\
\hline \multicolumn{13}{|c|}{$\begin{array}{l}\text { Liberty } \\
\text { eats }\end{array}$} \\
\hline B & neg. & $\mathrm{ND}$ & 4 & 103 & 500 & 83 & 63 & + & + & + & + & + \\
\hline $\mathrm{D}$ & neg. & ND & 3 & 14 & 10 & 23 & 33 & - & - & - & - & - \\
\hline $\mathrm{E}$ & neg. & $\mathrm{ND}$ & 5 & 30 & 104 & 65 & 238 & - & + & + & + & + \\
\hline $\mathrm{G}$ & neg. & ND & 4 & 43 & 51 & 178 & 97 & - & + & + & + & + \\
\hline \multicolumn{13}{|c|}{$\begin{array}{l}\text { Control } \\
\text { cats }^{8}\end{array}$} \\
\hline $\mathrm{H}$ & neg. & ND & neg. & ND & neg. & neg. & neg. & - & - & - & ND & - \\
\hline I & neg. & ND & neg. & ND & neg. & neg. & neg. & - & - & - & ND & - \\
\hline
\end{tabular}

a Cat 1 placed with cat $B ; 2$ with $D ; 3$ with $\mathrm{E} ; 4$ with $\mathrm{G}$

b KELA titers $\leq 1: 8$ considered negative

c Examination of feces for CVLPs by electron microseopy (EM). $+=$ =virus observed; $-=$ virus not observed

a Cornell cats were 6-weeks-old on the day of introduction and had not yet naturally seroconverted. Cornell colony cats routinely become $\mathrm{CV}$ antibody-positive at 5 8 weeks of age and remain seropositive indefinitely

e $\mathrm{ND}=$ not done

i Cats $\mathrm{H}$ and I were housed individually in the same room under the same conditions as the experimental cats and served as room controls 
converted while the Liberty cats remained seronegative. By 45 days, however, all 4 Liberty cats had seroconverted as had the remaining Cornell cat (no. 1). There appeared to be little correlation between the magnitudes of $\mathrm{CV}$ antibody titers of cohabiting cats. Fecal samples were not collected from the Cornell cats prior to introduction, but of the Liberty cats, only cat $\mathrm{B}$ was shedding CVLPs prior to introduction. After separation, eats 1 and $\mathrm{B}, 3$ and $\mathrm{E}$, and 4 and $\mathrm{G}$ were shedding CVLPs. Fecal samples from cats 2 and $\mathrm{D}$ were consistently CVLP-negative. Particles unequivocally recognizable as coronaviruses of the same morphology as FECV (UCD), TGEV, $\mathrm{CCV}$, and FIPV were never visualized in fecal samples. Room control cats $\mathrm{H}$ and $\mathrm{I}$ remained $\mathrm{CV}$ antibody- and CVLP-negative and no clinical signs of disease were seen in any of the cats.

These results indicate that Cornell colony cats shed a second infectious agent in addition to enteric CVLPs which is cross-reactive with TGEV and which appears to be transmitted by some route other than the lower gastrointestinal tract.
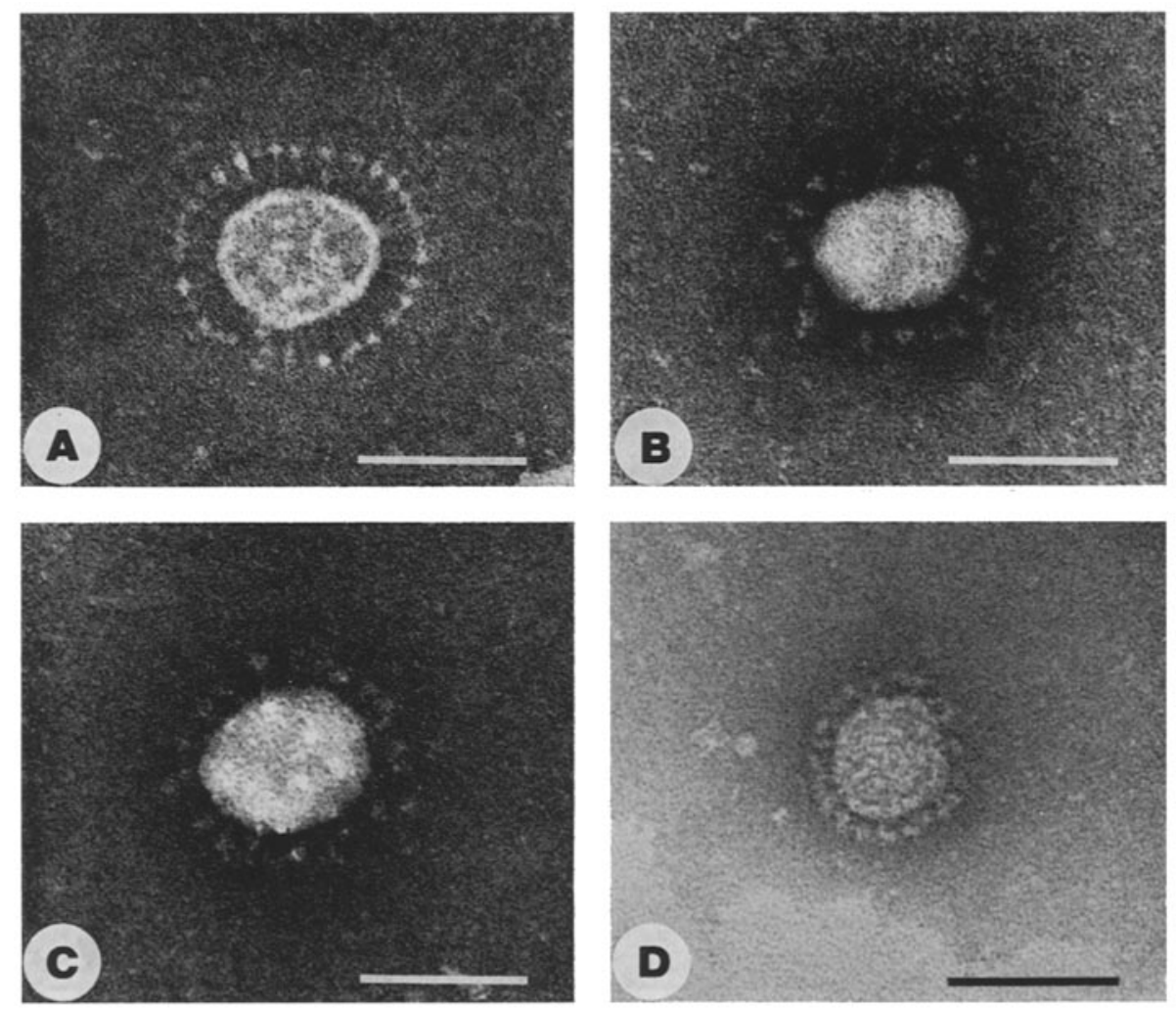

Fig, 1. Electron micrographs of negatively stained coronavirus-like particle and three "typical" coronaviruses for morphologie comparison. Bar represents $100 \mathrm{~nm}$. A feline enteric CVLP. $B$ FECV (UCD). $C$ TGEV. $D$ FIPV 


\section{Morphologic Comparison of CVLP and "Typical" CVs}

A comparison of CVLP and CV morphology is shown in Fig. 1. The CVLP projections were markedly different from those of the three "typical" CVs: FECV (UCD), FIPV, and TGEV. The peplomer fringe surrounding the CVLP was composed of regularly spaced teardrop-like knobs anchored to the particle by thin stalks. The total length of projections $(25 \mathrm{~nm})$ was uniform. The classical CV peplomers, however, were larger, more diffuse, and petal-shaped. The FECV (UCD) and TGEV peplomers were also not as regularly spaced and less uniform in length, ranging from $15-30 \mathrm{~nm}$.

\section{Discussion}

Enteric CVLPs are an enigmatic group of morphologically distinctive entities that have been identified by EM in feces of humans and a number of animal species, including cats $(11,13)$. Particles are moderately to markedly pleomorphic, ranging in diameter from 60 to over $1000 \mathrm{~nm}$, and possess regularly spaced radiating surface projections reminiscent of coronaviral peplomers. However, eloser examination reveals that CVLP projections consist of a knoblike structure anchored to the particle by a slender stalk, and thus are distinguishable from the larger, more massive petal-shaped peplomers of "typical" coronaviruses $(4,13)$. Feline enteric CVLPs appear to be morphologically distinet from established coronaviruses and also from a proposed feline enteric coronavirus, FECV (UCD), recently reported from California (14). To date CVLPs have not been positively identified as the cause of disease in any species (13). Further immunologic and physicochemical studies are required before it can be determined whether CVLPs are true members of the Coronaviridae or represent a new and distinct group of viral agents.

In this paper we report that exposure of MD cats to feline enteric CVLPs did not result in the production of antibodies reactive with TGEV as determined in a kinetics-based ELISA (KELA). Oronasal, intraperitoneal, intraduodenal, and intravenous routes of administration were uniformly unsuccessful in seroconversion of cats. This suggests that feline enteric CVLPs may be antigenically distinct from the FIPV/TGEV group of coronaviruses.

While remaining $\mathrm{CV}$ antibody-negative after exposure to fecal material from colony cats, MD cats nevertheless seroconverted following prolonged close contact with colony kittens. Most of these kittens, while seronegative at the time of introduction, became $\mathrm{CV}$ antibody-positive within 15 days, at which time their MD companion cats were still negative (Table 2). All cats were seropositive by 45 days after introduction. Moreover, subsequent placement of one seroconverted MD eat together with one seronegative MD cat resulted in seroconversion of the negative cat between 23 and 45 days 
after introduction (data not shown). The exact identity of the $\mathrm{CV}$ responsible for seroconversion has not been determined; isolation of a CV from this colony has been unsuccessful and no true coronavirions have been observed by EM in any fecal specimens to date. Data presented here suggest that fecal excretion of the TGEV-cross-reactive $\mathrm{CV}$ as infectious virus, if it occurs, is minimal, and that shedding probably occurs by some other route (respiratory, salivary, ete.).

After removal of colony kittens, MD cats $\mathrm{E}$ and $\mathrm{G}$ began shedding CVLPs in their feces (Table 2), although they had not shed prior to introduction of the kittens, even after repeated artificial inoculations (Table 1). The kittens to which they had been exposed ( 3 and 4 ) also shed CVLPs, suggesting that prolonged close contact with carrier cats may be required for efficient CVLP transmission. Kitten 2 did not shed CVLPs after removal, and its companion cat (D) also did not shed. However, both cats beeame CV antibody-positive, further supporting the conclusion that CVLPs and the seroconverting $\mathrm{CV}$ are distinct.

There are additional possible explanations for failure of CVLPs to produce a TGEV-cross-reactive antibody response in MD cats. For instance, CVLPs may have been inactivated or antigenically altered during processing of inocula. Viral peplomers, presumed mediators of attachment to target cells, may have been damaged or lost, producing particles incapable of infection. EM examination of CVLPs, however, has demonstrated that peplomer integrity is virtually unaffected by the storage, filtration, ultracentrifugation, and routine EM processing techniques used in this experiment (C. A. STODDaRT, unpublished data). This is in contrast to some reports of established CVs in which such methods can result in damaged virions, with extrusion of internal components and/or partial or complete denudation of the peplomer fringe $(9 ; \mathrm{C} . \mathrm{A}$. STOddart, unpublished data). The possibility also exists that subtle antigenic alteration of CVLP peplomers may not have been accompanied by detectable morphologic changes. The action of proteolytic enzymes in the gastrointestinal tract on the antigenic and morphologic stability of virus particles must also be considered (16).

Detection of antibodies cross-reactive with TGEV could also be dependent upon the serologic technique and/or reagents employed Some reports indicate that porcine antiserum to TGEV cannot detect FIPV antigen, suggesting one-way antigenic cross-reactivity between TGEV and FIPV $(19,20)$. At this time it is unclear whether a similar one-way serologic crossreaction might occur between TGEV and CVLPs and it is possible that while antibody to CVLPs may not detect TGEV in the KELA, anti-TGEV antibody may react with CVLPs in a reciprocal test.

Invasion of cells by CVLPs within the gastrointestinal tract may have produced only a low-grade focal infection without a systemic antibody response. Alternatively, CVLP infection may have stimulated only IgA 
and/or IgM production, but this possibility is less likely due to the combined heavy chain/light chain specificity of the conjugate used in the KELA. The antibody response induced by CVLP infection may have been so transient as to have been missed by the sampling intervals used. However, i.v. administration of CVLPs would presumably have induced a substantial systemic antibody response even if the virus were no longer infectious. Lastly, the cats used in these experiments may not have been susceptible to CVLP infection although persistence of CVLPs in feces of individual cats argues against a simple passive transit through the gastrointestinal tract. Thus we conclude that CVLPs do indeed infect cats, but the nature of the target cell(s) and the specificity of any resulting antibody response remain undetermined.

Further studies of feline enteric CVLPs are currently in progress in our laboratory. A cytopathic effect has been carried through initial passages in rhesus monkey fetal kidney (MA104) cells, and particles virtually identical in peplomer morphology to CVLPs have been identified by EM in cell culture preparations (C. A. Stoddart, unpublished data). These particles have been found to be generally smaller and less pleomorphic than CVLPs in cat feces, differences which have also been reported for human enteric CVs grown in human intestinal organ cultures (3). Seroepizootiologic studies hopefully will aid in our understanding of the distribution and importance of CVLPs in the feline population, and their relationship (if any) to feline CVs.

\section{Acknowledgments}

This work was supported by an anonymous grant from a private foundation and by private contributions to the Cornell Feline Health Center. The authors acknowledge the expert technical assistance of Cordell Geissinger, Debbie Alo, Cathy Shea, and Diann Bailey. We especially acknowledge the excellent assistance of Dr. Charles Baldwin in performing surgery and in EM consultation. We also thank Dr. N. C. Pedersen for providing samples of FECV (UCD) and FIPV (WSU 79-1146), and for sharing ideas and unpublished data.

\section{References}

1. Barlotgh, J. E., Jacobson, R. H., Downivg, D. R., Marceilla, K. L., Lynch, T. J., Scotr, F. W.: Evaluation of a computer-assisted, kinetics-based enzyme-linked. immuno sorbent assay for detection of coronaviral antibodies in cats. J. clin. Microbiol. 17, 202-217 (1983).

2. BohL, E. H.: Coronaviruses: Diagnosis of infections. In: Kurstak, E., Kurstak, C. (eds.), Comparative Diagnosis of Viral Diseases, Vol. IV, Part B, 301-328. New York: Academic Press 1981.

3. CAUL, E. O., EGgLestone, S. I.: Further studies on human enteric coronaviruses. Arch. Virol. 54, 107-117 (1977).

4. CAUL, E. O., EGGLESTONE, S. I. : Coronavirus-like particles present in simian faeces. Vet. Rec. 104, 168-169 (1979).

5. DeA, S., Rox, R. S., Ex.AzHARY, M. A. S. Y.: Coronavirus-like particles in the feces of a cat with diarrhea. Can. vet. J. 23, 153-155 (1982). 
6. Eugster, A. K., Ltauw, H.: Detection of antibodies to feline infectious peritonitis (FIP) virus in cats using transmissible gastroenteritis virus as antigen and an electronmicroscopic search for FIP virus. Southwestern Vet. 32, 109-112 (1979).

7. Hayashi, T., Watabe, Y., Nakayama, H., FuJIwara, K.: Enteritis due to feline infectious virus peritonitis. Jpn. J. vet. Sci. 44, 97-106 (1982).

8. Horztnek, M. C., Lutz, H., Pedersen, N. C.: Antigenie relationships among homologous structural polypeptides of porcine, feline, and canine coronaviruses. Infect. Immun. 37, $1148-1155$ (1982).

9. Horzinek, M. C., Osterhads, A. D. M. E., Ellens, D. J.: Feline infectious peritonitis virus. Zbl. Vet. Med. B. 24, 398-405 (1977).

10. Hoshino, Y., BaLdwin, C. A., Scotr, F. W.: New insights in gastrointenstinal viruses. Cor. Fel. Health Ctr. News, No. 2, 2-4 (1981).

11. Hoshino, Y., Scotr, F. W.: Coronavirus-like particles in the feces of normal cats. Arch. Virol. 63, 147-152 (1980).

12. Howatson, A. F.: Electron microscopic procedures in virology. In: HaBEL, K., Salzmax, N. P. (eds.), Fundamental Techniques in Virology, 505-524. NewYork: Academic Press 1969.

13. MacNaughton, M. R., Davies, H. A. : Human enteric coronaviruses. Arch. Virol. 70, $301-313(1981)$.

14. Pedersen, N. C., Boylt, J. F., Floyd, K., Fudge, A., Barker, J.: An enteric coronavirus infection of cats and its relationship to feline infectious peritonitis. Am. J. vet. Res. 42, 368-377 (1981).

15. Pedersen, N. C., Ward, J., Mengeling, W. L.: Antigenie relationship of the feline infectious peritonitis virus to coronaviruses of other species. Arch. Virol. 58, 45-53 (1978).

16. Pocock, D. H.: Effect of sulfhydryl reagents on the biological activities, polypeptide composition and morphology of haemagglutinating encephalomyelitis virus. J. gen. Virol. 40, 93-101 (1978).

17. Reynolds, D. J., Garwes, D. J., LuCEx, S.: Differentiation of canine coronavirus and porcine transmissible gastroenteritis virus by neutralisation with canine, porcine, and feline sera. Vet. Microbiol. 5, 283-290 (1980).

18. Tyrreld, D. A. J., Alexander, D. J., Almeida, J. D., Cunningham, C. H., Easterday, B. C., Garwes, D. J., Hterholzer, J. C., Kapikian, A., Macnaughton, M. R., McIntosh, K.: Coronaviridae: Second report. Intervirol. 10, $321-328(1978)$.

19. Wirahadiredja, R. M. S., Anakotta, J., Osterrhaus, A. D. M. E.: Detection by immunofluorescence of transmissible gastroenteritis (TGE) viral antigen in pigs, using cat anti-feline infectious peritonitis (FIP) virus conjugate. Zbl. Vet. Med. B. 25, $775-778(1978)$.

20. Witte, K. H., Tuch, K., Dubexkropp, H., Watther, C.: Untersuchungen über die Antigenverwandtschaft der Viren der Felinen Infektiösen Peritonitis (FIP) und der Transmissiblen Gastroenteritis (TGE) des Schweines. Berl. Münoh. tierärztl. Wschr. 90, 396-401 (1977).

Authors' address: C. A. SToddart, Cornell Feline Health Center, 618 VRT, NYS College of Veterinary Medicine, Ithaca, NY 14853, U.S.A.

Received December 23, 1982 